\title{
Pathology Laboratories Productivity Evaluation in Turkey
}

\section{Türkiye'de Patoloji Laboratuvarlarında Verimlilik Değerlendirmesi}

\author{
Kutsal YÖRÜKOĞLU', Sarp ÜNER'², Fevzi HARORLU', Alp USUBÜTÜN ${ }^{4}$ \\ ${ }^{1}$ Department of Pathology, Dokuz Eylül University, Faculty of Medicine, IZMIR, TURKEY, \\ Departments of ${ }^{2}$ Public Health and ${ }^{4}$ Pathology, Hacettepe University, Faculty of Medicine, ANKARA, TURKEY, \\ ${ }^{3}$ Department of Pathology, Bursa Ali Osman Sönmez Oncology Hospital, BURSA, TURKEY,
}

\begin{abstract}
Objective: Efficiency criteria and automation in pathology laboratories have been set in a limited number of studies usually originated from the United States. A questionnaire has been prepared to determine the situation and define the criteria for adaptation in our country.
\end{abstract}

Material and Method: The survey was sent to all pathology laboratories and, 302 responded. The survey questionned of pathology laboratories efficiencies, staff workloads, methods applied, devices used, and physical conditions. Work flow productivity was obtained by dividing the annual number of blocks to working hours multiplied by the number of technicians. The hospitals were categorized to 3 groups according to providing training or not and privacy, and to 4 groups according to the annual biopsy numbers. The data entered through the SPSS 16.0 statistical package program, analysis of distribution criteria, significance of the difference between means tests were used.

Results: The annual biopsy numbers were significantly higher in education units, but below the limit of productivity levels for all laboratories. The device hardware and automation correlated with annual biopsy numbers. However, the laboratories of limited capacity have redundant automation. Histochemical and immunohistochemical staining numbers were high. Liquid-based cytology techniques were used more significantly in private hospitals. Archiving times were not standard. A serious shortage of working space in service hospitals was noted. Work flow productivity in education units was at the border, and low in other units.

Conclusion: All pathology laboratories in our country should define and improve their productivities. Formalizing of archiving times is very important for future malpractice lawsuits.

Key Words: Pathology, Laboratory, Workflow, Productivity, Automation, Survey

\section{ÖZ}

Amaç: Patoloji laboratuvarlarının, kullanılan cihazların ve otomasyonun verimlilik kriterleri sınırlı sayıda çalışmalarda belirlenmiştir. $\mathrm{Bu}$ çalışmalar, genellikle Amerika Birleşik Devletleri kaynaklıdır. Ülkemizde ki durumun belirlenmesi ve kriterlerin ülkemiz koşullarına uyumunun sağlanması için bir anket hazırlanmıştır.

Gereç ve Yöntem: Anket, patoloji laboratuvarı olan tüm hastanelere gönderilmiş, 302 hastaneden geri dönüş olmuştur. Ankette, patoloji laboratuvarlarının verimlilikleri, çalışan personelin iş yükleri, uygulanan yöntemler, kullanılan cihazlar, fiziksel koşullarına yönelik sorular yöneltilmiştir. İş verimliliği, yıllık blok sayısının, yıllık çalışma saatinin teknisyen sayısı ile çarpımına bölünerek elde edilmiştir. Hastaneler, eğitim veren, vermeyen ve özel olmak üzere 3 gruba, tüm laboratuvarlar ayrıca materyal sayılarına göre 4 gruba ayrılmıştır. Veriler SPSS 16,0 istatistik paket programı aracılığıly girilmiş, analizlerde dağılım ölçütleri, ortalamalar arası farkın önemlilik testleri kullanılmıştır.

Bulgular: Yıllık biyopsi sayısı eğitim veren birimlerde belirgin olarak yüksektir ama genelde tüm birimlerde yıllık biyopsi sayısının verimlilik sınırı altında olduğu gözlenmektedir. Cihaz donanımı ve otomasyon, yıllık biyopsi sayısı ile ilişkilidir. Ancak, sınırlı kapasiteli laboratuvarlarda gereksiz otomasyon olduğu dikkati çekmektedir. Histokimya ve özellikle immünohistokimyasal boyama sayısının yüksek olduğu izlenmektedir. Sitolojik yöntemlerden sıvı bazlı teknikler, özel hastanelerde belirgin olarak daha fazla kullanılmaktadır. Arşivleme süreleri konusunda da bir standartın olmadığı saptanmaktadır. Özellikle hizmet hastanelerinde ciddi çalışma alanı sıkıntısı olduğu anlaşılmaktadır. İş verimliliğinin ise eğitim veren birimlerde sınırda, diğer birimlerde ise düşük olduğu gözlenmektedir.

Sonuç: Ülkemizdeki tüm patoloji laboratuvarlarının, kendi verimliliklerini değerlendirmeleri ve iyileştirmeye gitmeleri gerekmektedir. Daha iyi fiziki koşulların sağlanması için idari birimlerin desteği sağlanmalıdır. Patolojiye özel arşivleme sürelerinin resmiyete dökülmesi, ileride doğabilecek meslek hatası yargılamaları için çok önem göstermektedir.

Anahtar Sözcükler: Patoloji, Laboratuvar, İş verimliliği, Otomasyon, Anket

\section{Correspondence: Kutsal YÖRÜKOĞLU}

Department of Pathology, Dokuz Eylül University, Faculty of Medicine, IZMIR, TURKEY

E-mail: kutsal.yorukoglu@deu.edu.tr Phone: +90 2324123410 


\section{INTRODUCTION}

The pathology report is the product in pathology. The major sources for the generation of this report are macroscopic and microscopic investigations. Proper sampling and processing of tissues and liquids are required for microscopic investigations. Processing of tissues and liquids is a long process and all the steps of this process can be done manually. However, in laboratories in which the number of materials is high, it is desired to automate almost all of the operations with the use of devices in order to rush and standardize the work, and to obtain the product with lower number of workers at lower cost. Similar automation processes are also valid for conventional histochemistry and immunohistochemistry techniques, which are used besides histological Hematoxylin-Eosin (H\&E) and cytological H\&E or similar (like Papanicolaou) stained smears required for standard microscopic investigations. Technological advancements cause cheapening of devices day by day in pathology, as it does in general industry (1). However, it cannot be denied that redundant devices are being purchased for some manually executable and easy operations.

In a nationally-scaled survey carried out by the Standardization Commission of the Turkish Federation of Pathology Societies, it was shown that automation was related to the number of materials and the establishment date of the unit in our country (2). In another survey performed on an international scale, working conditions in pathology laboratories were determined globally, and the most productive threshold values for automation were stated (3).

A new survey study for pathology laboratories of public hospitals in Turkey was carried out by the Standardization Commission of the Turkish Federation of Pathology Societies with the support of the Ministry of Health, and the distribution and productivity of country-wide pathology laboratories, and the workload of workers employed in these laboratories were presented as an article (4). Here, the results of the same survey are evaluated in terms of automation and laboratory productivity.

\section{MATERIAL and METHOD}

The universe of the descriptive study consisted of Ministry of Health hospitals, university hospitals, and private hospitals which have pathology laboratories. No sample was chosen and we tried to reach all of the hospitals.

The number of beds, number and distribution of materials, units sending materials, devices used, methods employed, laboratories and working spaces, quality and number of workers, and required time for reporting and archiving were questioned with the survey form prepared.

Work Flow Productivity (WFP) was obtained by dividing the annual block number by multiplication of annual work hours and number of technicians (Work Flow Productivity = Annual block number / $2080 \mathrm{x}$ number of technicians). Hospitals were separated into 3 groups as training, nontraining and private, and all of the laboratories were divided into 4 groups according to the number of material received as $<10.000,10.001-20.000,20.001-30.000$, and $>30.001$. Differences between the groups were calculated.

Data were entered using the SPSS 16.0 statistical package program, and distribution measures were used for analyses while variance analyses were used to determine whether there was a significant difference between measurement values when there were more than two groups. When the differences between the groups were determined to be significant, the group the significance originated from was assessed with the LSD (least significant difference) test, one of the "post-hoc" tests.

\section{RESULTS}

The survey was sent to all of the hospitals, and 302 hospitals (35 University [UH], 41 Ministry of Health Training [TH], 185 Ministry of Health Service [SH] and 41 Private Hospitals [PH]) replied.

The distribution of these pathology units according to their number of biopsies is presented in Table I. Biopsy numbers were greater in $\mathrm{UH}$ and $\mathrm{TH}$.

Annual biopsy, cytology, intra-operative consultation, block and slide numbers varied considerably between hospitals $(\mathrm{p}<0.01)$ (Table II). All parameters were greater in $\mathrm{UH}$ and TH compared to other hospitals.

These variables correlated positively with the number of beds, and this relation was statistically significant $(\mathrm{p}<0.01$, $\mathrm{r}=0.553-0.767$ ).

When the hospitals were grouped according to their number of biopsies, the number of slides per block was greater in units with 20.001-30.001 biopsies, but the number of blocks per biopsy was also smaller in these units (Table III).

Evaluation of the distribution of devices used in routine work showed that the numbers of macroscopy cabinets, microtomes, frozen devices, and light microscopes varied between the hospitals (Table IV). However, the number of cytocentrifuge devices showed no difference. 
Table I: Distribution of hospitals according to number of biopsies

\begin{tabular}{|l|c|c|c|c|c|}
\hline Hospital & $<\mathbf{1 0 . 0 0 0}$ & $\mathbf{1 0 . 0 0 1 - 2 0 . 0 0 0}$ & $\mathbf{2 0 . 0 0 1 - 3 0 . 0 0 0}$ & $\mathbf{> 3 0 . 0 0 1}$ & Total \\
\hline University & 22 & 6 & 4 & 1 & 33 \\
\hline Training MH & 22 & 13 & 3 & 1 & 39 \\
\hline Service MH & 172 & 3 & - & - & 175 \\
\hline Private & 36 & - & - & - & 36 \\
\hline Total & 252 & 22 & 7 & 2 & 283 \\
\hline
\end{tabular}

Table II: Distribution of hospitals' annual biopsy, cytology, intra-operative consultation, block and slide numbers

\begin{tabular}{|c|c|c|c|c|}
\hline & $\mathbf{N}$ & Min-Max (Mean \pm SD) & $\mathbf{F}$ & $\mathbf{p}$ \\
\hline \multicolumn{5}{|c|}{ Annual biopsy number } \\
\hline University & 33 & $1.031-43.800(10.080 .7 \pm 9.504,7)$ & \multirow{5}{*}{41.7} & \multirow{5}{*}{$<0.01$} \\
\hline Training $\mathrm{MH}$ & 39 & $600-30.611(10.603 .2 \pm 7102,9)$ & & \\
\hline Service MH & 175 & $75-13.303(3.459 .0 \pm 2.520,6)$ & & \\
\hline Private & 36 & $510-9.067(2.617 .4 \pm 1.624,9)$ & & \\
\hline Total & 283 & $75-43.800(5.108 .6 \pm 5.553,9)$ & & \\
\hline \multicolumn{5}{|c|}{ Annual cytology number } \\
\hline University & 33 & $301-16.375(5.510 .5 \pm 4.374,9)$ & \multirow{5}{*}{37.1} & \multirow{5}{*}{$<0.01$} \\
\hline Training $\mathrm{MH}$ & 36 & $550-22.016(8.112 .1 \pm 5.514,9)$ & & \\
\hline Service MH & 147 & $60-15.000(2.327 .9 \pm 2.249,9)$ & & \\
\hline Private & 34 & $200-8.900(2.462 .4 \pm 1.704,1)$ & & \\
\hline Total & 250 & $60-22.016(3.599 .3 \pm 3.827,1)$ & & \\
\hline \multicolumn{5}{|c|}{ Annual frozen number } \\
\hline University & 30 & $40-2.400(490.3 \pm 547,5)$ & \multirow{5}{*}{10.5} & \multirow{5}{*}{$<0.01$} \\
\hline Training $\mathrm{MH}$ & 36 & $10-2.340(386.6 \pm 497,7)$ & & \\
\hline Service MH & 40 & $1-588(46.1 \pm 95,2)$ & & \\
\hline Private & 23 & $5-508(103.1 \pm 130,3)$ & & \\
\hline Total & 129 & $1-2.400(254.6 \pm 420,7)$ & & \\
\hline \multicolumn{5}{|c|}{ Annual block number } \\
\hline University & 33 & $2.430-250.000(46.075,6 \pm 46.676,6)$ & \multirow{5}{*}{34.7} & \multirow{5}{*}{$<0.01$} \\
\hline Training MH & 39 & $1.000-135.000(38.027,9 \pm 33.969,9)$ & & \\
\hline Service MH & 158 & $200-62.208(11.012,0 \pm 10.893,8)$ & & \\
\hline Private & 32 & $150-12.280(6.348,6 \pm 3.301,9)$ & & \\
\hline Total & 262 & $150-250.000(18.880,3 \pm 26.699,1)$ & & \\
\hline \multicolumn{5}{|c|}{ Annual slide number } \\
\hline University & 33 & $4.156-450.000(92.942,7 \pm 91.258,5)$ & 36.5 & $<0.01$ \\
\hline Training MH & 38 & $6.750-500.000(88.875,3 \pm 91.544,5)$ & & \\
\hline Service MH & 162 & $300-200.000(81.796,1 \pm 21.565,9)$ & & \\
\hline Private & 33 & $750-130.000(15.953,2 \pm 22.407,9)$ & & \\
\hline Total & 266 & $300-500.000(37.147,3 \pm 59.759,5)$ & & \\
\hline
\end{tabular}


Table III: Number of blocks per biopsy and slides per block for hospitals grouped according to number of biopsies

\begin{tabular}{|l|r|r|r|c|}
\hline Annual biopsy number & \multicolumn{2}{|c|}{ Slide/Block } & \multicolumn{2}{c|}{ Block/Biopsy } \\
\hline & $\mathbf{N}$ & Mean \pm SD & N & Mean \pm SD \\
\hline$<10.000$ & 192 & $2.00 \pm 1.74$ & 193 & $3.34 \pm 2.03$ \\
\hline $10.001-20.000$ & 22 & $2.28 \pm 1.13$ & 22 & $3.81 \pm 1.76$ \\
\hline $20.001-30.000$ & 7 & $6.15 \pm 7.50$ & 7 & $2.80 \pm 2.04$ \\
\hline$>30.000$ & 2 & $1.51 \pm 0.41$ & 2 & $5.06 \pm 0.91$ \\
\hline
\end{tabular}

Table IV: Numerical distribution of devices used in routine work

\begin{tabular}{|c|c|c|c|}
\hline & $\mathbf{N}$ & Min-Max (Mean) & $\mathbf{p}$ \\
\hline \multicolumn{4}{|c|}{ Number of macroscopy cabinets } \\
\hline University & 22 & $1-6(1.9)$ & \multirow{5}{*}{$<0.001$} \\
\hline Training MH & 24 & $1-3(1.5)$ & \\
\hline Service MH & 90 & $1-1(1.0)$ & \\
\hline Private & 18 & $1-2(1.1)$ & \\
\hline Total & 154 & $1-6(1.2)$ & \\
\hline \multicolumn{4}{|c|}{ Number of microtomes } \\
\hline University & 34 & $1-8(2.3)$ & \multirow{5}{*}{$<0.001$} \\
\hline Training MH & 40 & $1-5(2.3)$ & \\
\hline Service MH & 174 & $1-3(1.2)$ & \\
\hline Private & 35 & $1-2(1.1)$ & \\
\hline Total & 283 & $1-8(1.5)$ & \\
\hline \multicolumn{4}{|c|}{ Number of frozen devices } \\
\hline University & 31 & $1-3(1.4)$ & \multirow{5}{*}{$<0.001$} \\
\hline Training MH & 35 & $1-2(1.2)$ & \\
\hline Service MH & 43 & $1-2(1.0)$ & \\
\hline Private & 19 & $1-1(1.0)$ & \\
\hline Total & 128 & $1-3(1.2)$ & \\
\hline \multicolumn{4}{|c|}{ Number of cytocentrifuge devices } \\
\hline University & 30 & $1-4(1.2)$ & \multirow{5}{*}{0.133} \\
\hline Training MH & 27 & $1-2(1.1)$ & \\
\hline Service MH & 62 & $1-2(1.0)$ & \\
\hline Private & 18 & $1-1(1.0)$ & \\
\hline Total & 137 & $1-4(1.1)$ & \\
\hline \multicolumn{4}{|c|}{ Number of light microscopes } \\
\hline University & 34 & $1-23(6.7)$ & 0.001 \\
\hline Training MH & 41 & $1-18(5.8)$ & \\
\hline Service MH & 184 & $1-6(1.8)$ & \\
\hline Private & 41 & $1-5(1.2)$ & \\
\hline Total & 300 & $1-23(2.8)$ & \\
\hline
\end{tabular}

The number of light microscopes correlated with the number of biopsies $(\mathrm{p}<0.001)$. There was one microscope per 5.077 biopsies on average. Similarly, the number of annual biopsies also correlated with the number of microtomes ( $\mathrm{p}<0.001,1$ for 5.077 biopsies), macroscopy cabinets ( $\mathrm{p}<0.001,1$ for 5.108 biopsies), tissue processing devices ( $\mathrm{p}<0.001,1$ for 5.108 biopsies), tissue embedding devices $(\mathrm{p}<0.001,1$ for 5.108 biopsies), frozen devices ( $\mathrm{p}<0.001,1$ for 5.108 biopsies), and macroscopic photography devices ( $\mathrm{p}<0.001,1$ for 5.108 biopsies).

The numbers of automatic tissue processing devices, tissue embedding devices, automatic slide staining devices, automatic slide mounting devices, cassette and slide printers, automatic immune staining devices and macroscopy dissection tables also varied between hospitals $(\mathrm{p}<0.01)$.

Automation was observed to be related to the annual number of biopsies. The annual number of biopsies was $8.713(\mathrm{p}<0.001)$ for units using automatic slide staining devices, 11.584 for units with automatic mounting devices $(\mathrm{p}<0.001), 13.415$ for units with automatic cassette/slide printers $(\mathrm{p}<0.001)$, and 14.261 for units with automatic immune staining devices $(\mathrm{p}<0.001)($ Table $\mathrm{V})$.

In addition to routine examinations, there was also a relation between the annual number of biopsies and employment of advanced examination methods as immunofluorescence and molecular techniques.

Regarding methods used in cytology, direct smear and centrifuge-prepared methods did not differ among hospitals, but the use of cytocentrifugation, cell blocks and liquid based methods did $(\mathrm{p}<0.01, \mathrm{p}<0.01, \mathrm{p}<0.01$, respectively). Cytocentrifugation method was used in almost all hospitals, while cell blocks were preferred in $\mathrm{UH}$ and TH. Liquid based methods were used more commonly in $\mathrm{UH}$ and $\mathrm{PH}$. The use of cytocentrifuge devices also seemed to be related to the number of biopsies $(\mathrm{p}<0.001)$. 
Table V: Distribution of devices used with automation purpose according to number of biopsies

\begin{tabular}{|c|c|c|c|}
\hline Number of biopsies & $\mathbf{N}$ & Min-Max (Mean) & $\mathbf{p}$ \\
\hline & \multicolumn{3}{|c|}{ Number of automatic tissue processing device } \\
\hline$<10.000$ & 218 & $1-3(1,1)$ & \multirow{4}{*}{$<0.001$} \\
\hline $10.001-20.000$ & 21 & $1-3(1,6)$ & \\
\hline $20.001-30.000$ & 7 & $1-6(2,4)$ & \\
\hline \multirow[t]{2}{*}{$>30.000$} & 2 & $2-5(3,5)$ & \\
\hline & \multicolumn{3}{|c|}{ Number of tissue embedding devices } \\
\hline$<10.000$ & 172 & $1-2(1,0)$ & \multirow{4}{*}{$<0.001$} \\
\hline $10.001-20.000$ & 18 & $1-2(1,2)$ & \\
\hline $20.001-30.000$ & 7 & $1-4(2,1)$ & \\
\hline \multirow[t]{2}{*}{$>30.000$} & 2 & $1-2(1,5)$ & \\
\hline & \multicolumn{3}{|c|}{ Number of automatic staining devices } \\
\hline$<10.000$ & 68 & $1-2(1,0)$ & \multirow{4}{*}{$<0.001$} \\
\hline $10.001-20.000$ & 17 & $1-2(1,1)$ & \\
\hline $20.001-30.000$ & 7 & $1-3(1,6)$ & \\
\hline \multirow[t]{2}{*}{$>30.000$} & 2 & $1-3(2,0)$ & \\
\hline & \multicolumn{3}{|c|}{ Number of automatic slide mounting devices } \\
\hline$<10.000$ & 32 & $1-1(1,0)$ & \multirow{4}{*}{ * } \\
\hline $10.001-20.000$ & 14 & $1-1(1,0)$ & \\
\hline $20.001-30.000$ & 7 & $1-2(1,1)$ & \\
\hline \multirow[t]{2}{*}{$>30.000$} & 2 & $1-1(1,0)$ & \\
\hline & \multicolumn{3}{|c|}{ Number of cassette and slide printers } \\
\hline$<10.000$ & 9 & $1-2(1,3)$ & \multirow{4}{*}{ * } \\
\hline $10.001-20.000$ & 8 & $1-2(1,3)$ & \\
\hline $20.001-30.000$ & 4 & $1-2(1,3)$ & \\
\hline \multirow[t]{2}{*}{$>30.000$} & 1 & $2-2(2,0)$ & \\
\hline & \multicolumn{3}{|c|}{ Number of automatic immune staining devices } \\
\hline$<10.000$ & 18 & $1-2(1,1)$ & * \\
\hline $10.001-20.000$ & 4 & $1-1(1,0)$ & \\
\hline $20.001-30.000$ & 7 & $1-3(1,7)$ & \\
\hline$>30.000$ & 2 & $1-3(2,0)$ & \\
\hline
\end{tabular}

*: Statistical analysis was not carried out since the unit numbers were insufficient.

Autopsy procedures were more frequent in training hospitals $(\mathrm{p}<0.01)$ but it was remarkable that many hospitals did not have autopsy rooms.

When the variability between hospitals was evaluated with respect to archiving, there was no difference in the storage time of sample fixed tissues ( $\mathrm{p}=0.536$ ), but differences in storage time of reports, blocks and preparations were observed ( $\mathrm{p}=0.006, \mathrm{p}<0.001, \mathrm{p}<0.001$, respectively). The shortest time for the storage of reports was 10 years in $\mathrm{UH}$, 5 years in $\mathrm{PH}$ and $\mathrm{TH}$, and 2 years in $\mathrm{SH}$. No significant difference was found between $\mathrm{TH}, \mathrm{SH}$ and $\mathrm{PH}$ in the storage time of the reports. Nonetheless, it was observed that storage times were longer in $\mathrm{UH}$ compared to other units. The shortest time for the storage of blocks was 10 years in UH, 5 years in $\mathrm{TH}$ and $\mathrm{PH}$, and 3 years in $\mathrm{SH}$. The storage time in SH was statistically significantly shorter compared to other units. The shortest time for the storage of preparations was 10 years in $\mathrm{UH}, 3$ years in $\mathrm{SH}$ and $\mathrm{PH}$, and 5 years in $\mathrm{TH}$. The longest time for the storage of reports, blocks and preparations was 'continuous' for all units. The storage time of sampled and fixed tissues was stated to be 10-15 days. Out of the 265 units which responded to the survey, reports 
had never been discarded since establishment in 166 units $(62.6 \%)$, were stored for less than 20 years in $85(32.1 \%)$, and stored for 20 years or longer in 14 (5.3\%); blocks had never been discarded since establishment in 125 units (47.2\%), were stored for less than 20 years in 127 (47.9\%), and stored for 20 years or longer in 13 (4.9\%); slides had never been discarded since establishment in 131 units (49.1\%), were stored for less than 10 years in $27(10.1 \%)$, and stored for 10 years or longer in 109 (40.1\%). Out of the 228 units which responded, sampled fixed tissues were stored for less than 1 month in 39 units (17.1\%).

Distinctive differences were revealed between the hospitals when we analyzed the numbers for immunohistochemistry and immunofluorescence staining (Table VI). The numbers for histochemical staining were distinctively greater in $\mathrm{UH}$ and $\mathrm{TH}$ compared to $\mathrm{SH}$ and $\mathrm{PH}(\mathrm{p}<0.01)$. The numbers for immunohistochemical staining was observed to be significantly smaller or greater in $\mathrm{UH}$ compared to TH $(\mathrm{p}<0.01)$. Furthermore, the number of immunohistochemical stainings performed in $\mathrm{UH}$ and in $\mathrm{TH}$ were greater than that of $\mathrm{SH}$ and $\mathrm{PH}(\mathrm{p}<0.01)$. The number of immunofluorescence stainings was greater in $\mathrm{UH}$ compared to other hospitals $(\mathrm{p}<0.01)$.

Use of histochemistry and immunohistochemistry that help the diagnosis was observed to be related to the number of biopsies. In units where the number of biopsies was $<10.000$ annually, the numbers for both methods (respectively 1.143 and 464 per year) was relatively smaller. When the number of biopsies increased to more than 10.000, the annual number increased remarkably (Table VII).

Evaluation of the sizes of departments such as laboratories, laboratory sub-divisions, offices, study and archive areas, and meeting rooms showed that all areas varied among hospitals. The total area differed between 8 and $908 \mathrm{~m}^{2}$ $\left(101,1 \pm 114,9 \mathrm{~m}^{2}\right)$ in the 274 units which responded to the survey. The total area of the laboratory was smaller than 50 $\mathrm{m}^{2}$ in 94 units and 4 of these were $\mathrm{UH}, 3$ were $\mathrm{TH}, 72$ were $\mathrm{SH}$ and 15 were $\mathrm{PH}$.

If we examine these areas individually, secretarial areas were larger in $\mathrm{UH}$ than $\mathrm{TH}(\mathrm{p}=0.001)$, and in $\mathrm{UH}$ and $\mathrm{TH}$ compared to other hospitals $(\mathrm{p}<0.001, \mathrm{p}=0.015)$.

Routine laboratory areas did not differ between $\mathrm{UH}$ and $\mathrm{TH}$, but seemed to be distinctively larger in $\mathrm{UH}$ and $\mathrm{EH}$ compared to $\mathrm{SH}$ and $\mathrm{PH}(\mathrm{p}<0.001)$.

Macroscopy and microscopy room areas were larger in $\mathrm{UH}$ compared to other hospitals including TH $(\mathrm{p}<0.001)$. These areas were larger in $\mathrm{TH}$ compared to $\mathrm{SH}$ and $\mathrm{PH}(\mathrm{p}=0.001$ and $\mathrm{p}<0.001$ ). Macroscopy and microscopy room areas did not differ between $\mathrm{SH}$ and $\mathrm{PH}$.

The situation for the macroscopy and microscopy rooms was also valid for special staining areas (histochemistry/ immunohistochemistry). These areas were larger in $\mathrm{UH}$ than $\mathrm{TH}$, and in $\mathrm{UH}$ and $\mathrm{TH}$ than $\mathrm{SH}$ and $\mathrm{PH}(\mathrm{p}<0.001$, $\mathrm{p}=0.002, \mathrm{p}=0.009$, respectively). There was no difference between $\mathrm{SH}$ and $\mathrm{PH}$.

The archive area did not differ between $\mathrm{UH}$ and $\mathrm{TH}$, and between $\mathrm{SH}$ and $\mathrm{PH}$. However, it was observed to be larger in $\mathrm{UH}$ and $\mathrm{TH}$ compared to $\mathrm{SH}$ and $\mathrm{PH}(\mathrm{p}<0.001)$. Storage areas were greater in $\mathrm{UH}$ compared to $\mathrm{TH}, \mathrm{SH}$ and $\mathrm{PH}$ ( $\mathrm{p}=0.01, \mathrm{p}<0.001, \mathrm{p}<0.001$, respectively), in TH compared to $\mathrm{SH}(\mathrm{p}=0.03)$. There was no difference between $\mathrm{TH}$ and $\mathrm{SH}$, and $\mathrm{PH}$.

The area of the autopsy room was greater in UH compared to all other hospitals $(p<0.001)$ : However, there was no difference between the other hospitals.

The area of the meeting room was greater in $\mathrm{UH}$ than all other hospitals, and in $\mathrm{TH}$ than $\mathrm{SH}$ and $\mathrm{PH}(\mathrm{p}=0.003$, $\mathrm{p}=0.01$ ).

The areas of specialists' offices were greater in $\mathrm{UH}$ and $\mathrm{TH}$ than SH and PH ( $p=0.005, p=0.028, p<0.001$ and $p<0.001$, respectively).

The resting rooms for technicians were larger in $\mathrm{UH}$ compared to all other hospitals ( $\mathrm{p}=0.045, \mathrm{p}<0.001, \mathrm{p}<0.001$, respectively). In $\mathrm{TH}$, resting rooms for technicians were larger than in $\mathrm{SH}$ and $\mathrm{PH}(\mathrm{p}=0.007, \mathrm{p}=0.001$, respectively). There was no difference between $\mathrm{SH}$ and $\mathrm{PH}$.

Regarding work flow productivity (WFP), average WFP values were 3.9 in $\mathrm{UH}, 4.1$ in $\mathrm{TH}, 2.3$ in $\mathrm{SH}$ and 28 in $\mathrm{PH}$ $(\mathrm{p}<0.01)$, and values in $\mathrm{UH}$ and $\mathrm{TH}$ were significantly higher than in $\mathrm{SH}$ and $\mathrm{PH}$. When WFP was evaluated according to annual biopsy numbers, it was remarkable that average WFP was 2.5 in laboratories with annual biopsies $<10.000,4.7$ in laboratories with 10.001-20.000 biopsies, 3.9 in laboratories with 20.001-30.000 biopsies and 11.3 in laboratories $>30.001$ biopsies $(\mathrm{p}<0.01)$. WFP value was determined to be smaller in laboratories with $<10.000$ annual biopsies compared to laboratories with $>10.000$, while not different between laboratories with 10.001-20.000 and laboratories with 20.001-30.000, and statistically higher in laboratories with $>30.001$ annual biopsies compared to others. 
Table VI: Distribution of annual number of histochemical, immunohistochemical, and immunofluorescence stainings used to assist to diagnosis by hospital

\begin{tabular}{|c|c|c|c|c|c|c|c|}
\hline & $\mathbf{N}$ & Mean & Standard deviation & Minimum & Maximum & $\mathbf{F}$ & $\mathbf{p}$ \\
\hline \multicolumn{8}{|c|}{ Histochemistry } \\
\hline University & 29 & $4.543,4$ & $5.274,9$ & 246 & 20.000 & \multirow{5}{*}{10.303} & \multirow{5}{*}{$<0.01$} \\
\hline Training $\mathrm{MH}$ & 33 & $4.672,3$ & $5.105,9$ & 70 & 19.600 & & \\
\hline Service MH & 109 & $1.728,4$ & $2.166,6$ & 1 & 9.000 & & \\
\hline Private & 20 & $1.273,3$ & $2.441,9$ & 10 & 11.000 & & \\
\hline Total & 191 & $2.616,8$ & $3.701,2$ & 1 & 20.000 & & \\
\hline \multicolumn{8}{|c|}{ Immunohistochemistry } \\
\hline University & 26 & $8.770,2$ & $8.496,2$ & 60 & 35.000 & \multirow{5}{*}{8.579} & \multirow{5}{*}{$<0.01$} \\
\hline Training $\mathrm{MH}$ & 29 & $5.522,7$ & $8.137,1$ & 70 & 40.000 & & \\
\hline Service MH & 27 & 949,5 & $1.163,5$ & 3 & 4.500 & & \\
\hline Private & 12 & 296,3 & 275,5 & 20 & 1.000 & & \\
\hline Total & 94 & $4.440,1$ & $7.147,5$ & 3 & 40.000 & & \\
\hline \multicolumn{8}{|c|}{ Immunofluorescence } \\
\hline University & 23 & 771,8 & $1.079,8$ & 40 & 5.000 & \multirow{5}{*}{0.816} & \multirow{5}{*}{0.451} \\
\hline Training MH & 9 & 549,1 & 933,9 & 72 & 3.000 & & \\
\hline Service MH & - & - & - & - & - & & \\
\hline Private & 3 & 9.3 & 7.4 & 1 & 15 & & \\
\hline Total & 35 & 649,2 & 1004,3 & 1 & 5.000 & & \\
\hline
\end{tabular}

Table VII: Distribution of histochemical and immunohistochemical applications according to number of biopsies

\begin{tabular}{|l|c|}
\hline Number of biopsies/year & Mean \pm SD \\
\hline Histochemistry & $1.143 .0 \pm 2.252,0$ \\
\hline$<10.000$ & $4.745 .4 \pm 4.527,4$ \\
\hline $10.001-20.000$ & $8.937 .3 \pm 7.300,8$ \\
\hline $20.001-30.000$ & $10.675 .0 \pm 13.187,5$ \\
\hline$>30.001$ & $1.683 .2 \pm 3.265,5$ \\
\hline Total & $464.3 \pm 1.432,9$ \\
\hline Immunohistochemistry & $5.277 .3 \pm 6.230,4$ \\
\hline$<10.000$ & $16.263 .4 \pm 12.760,8$ \\
\hline $10.001-20.000$ & $22.000 .0 \pm 18.384,8$ \\
\hline $20.001-30.000$ & $1.381 .5 \pm 4.453,1$ \\
\hline$>30.001$ &
\end{tabular}

\section{DISCUSSION}

Results of a survey study carried out by the Standardization Commission of the Turkish Federation of Pathology Societies was published previously $(2,5)$. That survey represented a relatively limited section. A similar survey was carried out by extending the survey content and sending it to a greater number of institutions with the support of Ministry of Health.

The results of this survey have shown that the working capacity of pathology laboratories is related to the hospitals' number of beds $(\mathrm{p}<0.01)$. The Ministry of Health plans and classifies hospitals on a national scale according to their bed capacity and the population they serve. A similar system was tried for planning and equipping pathology laboratories. However, the opinion of the Standardization Commission of the Turkish Federation of Pathology Societies is such that, a planning based on population and/or bed capacity will not be appropriate in our country with the present conditions. In this aspect, the strategy report created by Standardization Commission of the Turkish Federation of Pathology Societies (6) was based on the number of biopsies, and the Ministry of Health abandoned planning based on the population/number of beds for pathology laboratories.

In a survey covering 325 pathology laboratories from all over the world, it was underlined that the most productive laboratories were those with more than 20.000 annual biopsies (3). We found the numbers of annual biopsies, cytology, frozen, blocks and slides to be distinctively greater 
in $\mathrm{UH}$ and $\mathrm{TH}$ than other hospitals. Of 283 laboratories responding to the survey, it is remarkable that only 9 had more than 20.000 annual biopsies and the annual biopsy number was less than 10.000 in 252 laboratories. The number of annual biopsies of almost all service hospitals was smaller than the ideal range which is 10.001-20.000, and the situation was also not ideal for the university and training hospitals. It is inevitable that a low number of annual biopsies will negatively affect training in training hospitals.

The mean annual number of frozen sections in service hospitals was 46 . This means 4 a month, and less than 1 a week. It may therefore be unnecessary to carry out frozen examinations at service hospitals.

Block numbers per biopsies were greater in laboratories with $>30.000$ biopsies per year. This situation is explained by preparation of more samples at training hospitals (3). The number of slides per block was observed to be very high in laboratories with 20.001-30.000 annual biopsies. When the numbers stated by these laboratories were evaluated, it appeared that they had written their annual consumption of slides.

The devices of the pathology laboratories seemed to be related to number of annual biopsies. Roughly, there was one microscope, microtome, macroscopy cabinet, tissue processing device, tissue embedding device, and frozen device per 5.000 annual biopsies. The presence of devices for automation was also related to annual biopsy numbers. The number of biopsies per automation device changed between 8.700 and 15.000 per year. At present, tissue processing and tissue embedding devices are accepted as absolute musts of pathology laboratories, like microscopes. It is possible to prepare 19 blocks per hour in the absence of a tissue embedding device but 40 with the device (3). Manual tissue processing cause delays in the preparation of microscopic cases for observation by 1 day, in addition to an increase in solution consumption and loss of work power (7). Thus, determination of the productivity threshold of these devices seems to be difficult. However, there will not be much work to be done by technicians after the cases are prepared for microscopic evaluation in laboratories with less than 10.000 annual biopsies (3). When device costs are also considered, it can be stated that tissue processing devices would especially be logical for laboratories with more than 10.000 annual biopsies. The embedding procedure constitutes $40 \%$ of all laboratory work (3). It may be reasonable to calculate threshold values in countries working in shifts such as the USA, but the rationality of embedding devices can be determined according to the number of technicians in laboratories whose annual biopsy number is small in our country. The important point here is that manual embedding is the procedure that takes the longest time, one must be sure that the absence of an embedding device does not affect the reporting time.

Devices indicating automation should be considered in a different way. Compared to manual operations, slide printing device is faster by $24 \%$, staining device by $50 \%$, a slide mounting device 3 fold, and a film mounting device 11 fold faster (3). In the USA, an automatic staining device is present in $75 \%$ and an automatic mounting device in $65 \%$ of the laboratories while these numbers are $32 \%$ and $22 \%$ in other countries (3). It is reported that the majority of laboratories in the USA employing automatic staining devices also use automatic mounting devices (3). In our survey, the degree of automation correlated with the biopsy number. While both automatic staining and mounting devices were present in 56 laboratories, only staining devices were used in 46 laboratories. It is notable that only slide mounting devices were present in 2 laboratories. A single technician is required for manual staining and mounting in laboratories handling 100 cases ( 320 blocks, 480 slides) per day (3). When calculated according to technician salaries in the USA, the automation of staining and mounting procedures would pay for themselves in less than 4 years in a laboratory where the annual number of biopsies is greater than 20.000 (3). However it is notable that there are 68 with automatic staining devices and 32 with automatic slide mounting devices among laboratories whose annual number of biopsies are $<10.000$ in our country. Among the laboratories with $<20.000$ biopsies annually, automatic staining was present in 85 , automatic slide mounting in 46 , cassette and slide printers in 17 and automatic immune staining devices in 22.

The devices which should ideally be present in a pathology laboratory and their numbers can be determined considering the following factors:

1. In our country, there are no work shifts except for exceptional units. All employers work during the same period. Some of the devices are therefore used at certain times of the day, and remain idle at other times.

2. The productivity limit of technicians and pathologists as determined by the Standardization Commission of the Turkish Federation of Pathology Societies are as follows: a. 1 pathologist for 3.000-4.000 biopsies per year in non-training units, b. 1 pathologist for 2.000 biopsies per year in training hospitals, c. As many technicians as pathologists, d. +1 technician in units performing autopsy, immunohistochemistry, molecular techniques 
and cytology, e. +2 technicians in training hospitals, f. 1 secretary for 2 pathologists, g. 1 microscopy technician for 3 pathologists.

3. The duration the workers should use these devices during the day to complete the work they are responsible for.

4. Worker safety and environment protection.

5. Cost of purchase and maintenance of devices.

6. Pay off time for the device.

7. The time needed for manual performance of the work in question and the required staff hours.

We believe that it is not appropriate to determine a requirement and number for macroscopy cabinets. There is no need for macroscopy cabinets, if there is enough and proper air conditioning, if the formalin concentration is under the respiration limits, and if the macroscopy room/ department is structured properly. It is also not required if the laboratory in question can establish ideal conditions without the need of a macroscopy cabinet purchase. However, the purchase of macroscopy cabinet will be the best solution if an ideal macroscopy arrangement cannot be established due to factors such as the physical structure of the laboratory. The required number can be determined considering how many stations are used at the same time.

A tissue processing device should be present in each laboratory. However, manual tissue processing can be used if immunohistochemistry and cytology are not performed in the laboratory and if the annual number of biopsies is $<5.000$. Tissue processing devices are also not required in laboratories working mainly on cytology and with annual number of biopsies $<3.000$. In laboratories whose annual biopsy number is $<20.000$, the use of carousel type tissue processing devices is adequate. Closed system devices should be preferred in laboratories with a higher number of biopsies.

A total of 120 blocks can be prepared in one hour using an embedding device whereas only 50 blocks can be prepared without it. A tissue embedding device should be present in every laboratory whose annual number of biopsies is $>5.000$ excluding cytology.

In a laboratory with an annual number of 10.000 biopsies, 37-40 cases, 130 blocks and 200 slides are obtained on a daily basis. The time for printing one slide is 20 seconds. This means that 67 minutes will be spent for slide printing in a laboratory with this number of biopsies (3). A slide printing device should be preferred in laboratories with an annual number of biopsies $>20.000$. While no information is available on duration of cassette printing, it can be said that cassette printing devices should be preferred in laboratories whose annual number of biopsies is $>20.000$ considering that conditions are similar to slide printing.

The ideal number of microtomes is the number of technicians who perform sectioning. If a number is needed per biopsy, it could be 1 microtome per 3.000-4.000 biopsies in a laboratory with annual number of biopsies $<10.000 .1$ microtome per 6.000-8.000 biopsies might be enough for laboratories whose annual number of biopsies is $>10.000$.

A frozen device should be present in all laboratories providing intra-operative consultation. Portable devices are sufficient in laboratories where the intra-operative consultation number is $<300$ per year. If this number is exceeded, a higher capacity device should be used.

Staining and mounting devices pay themselves off in 4 years in laboratories where the daily case number is 100 . Consequently, staining and mounting devices should be preferred in laboratories whose annual number of biopsies is $>20.000$.

During preparation of non-gynecological cytologies (effusion, urine, etc.), a smear can be made from the pellet after centrifugation of the liquid, or smears and/or cell blocks can be prepared by cytocentrifugation of the pellet. Considering the time spent and consequently the technicians needed for preparation of a direct smear, and the fact that the time spent by the pathologist to screen these smears will be longer than for direct smears, the use cytocentrifuge device would be appropriate in laboratories where non-gynecologic cytology number is $>1.000$.

It is stated that the number of immunohistochemistries performed is 1 per 1.5 cases (3). 1 technician can perform 7.000 immunohistochemical stainings per year. Automation becomes productive when annual immunohistochemistry number is $>15.000$. In other words, an immunohistochemistry staining device should be present in laboratories where the annual biopsy number is $>20.000$. It is redundant in laboratories whose annual number of biopsies is $<10.000$. In laboratories where the annual biopsy number is $10.000-20.000$, it would be appropriate to decide according to the number of technicians and the other requirements of the laboratory.

The ideal is 1 microscope per pathologist in non-training hospital laboratories thought to work productively. Microscopes can be shared with good planning in training hospitals since the pathologist will have duties other than routine work and the number of microscopes in laboratories might be $1 / 2-2 / 3$ per pathologist in 
laboratories with more than 20.000 biopsies per year (i.e. more than 10 pathologists). Nonetheless, here the ideal case is again 1 microscope per pathologist. To re-define according to the number of biopsies, 0.5-1 microscope per 2.000 biopsies in $\mathrm{TH}$, and 1 microscope per 4.000 biopsies in other hospitals is required. A polarized light attachment should be present in the same number as the number of rooms with microscopes.

We feel that immunofluorescence staining should be limited to training institutions. An immunofluorescence microscope should be present in all laboratories performing immunofluorescence staining.

It is sufficient for electron microscopes to be present as 1 hospital in each geographical region, provided that it is in one of the university hospitals. Other hospitals may buy service from here.

While 2 technicians need to work for 26 hours for 110 immunohistochemical stainings in a pathology laboratory, the procedure takes 1 technician and 11 working hours with an automatic staining device (3). Repetitive immunohistochemical staining constitutes the highest expenditure in a pathology laboratory $(8,9)$. It is required to consider the cost, as well as the effect of automation on procedure time, while searching for a threshold value for automation of immunohistochemical staining. Values of 10-50\$ are given in the literature for the cost of one immunohistochemical staining $(8,9)$. Preparation of solutions in the laboratory instead of using ready-touse solutions achieves great savings (8). In the USA, 1 immunohistochemical staining is performed per 1.5 cases (3). It is notable that this number is a little bit higher in Turkey. While it is not often used in hospitals where the annual number of biopsies is less than 10.000 , it rises to roughly 1 per 1 case in units where the annual number of biopsies is between 10.000 and 20.000 and to 1.2 per 1 case in units where the annual number of biopsies is greater than 20.000 . The reasons for the increase in these numbers are beyond the scope of this article. Using quality control precautions before the automation will give better results for standard and high-quality immunohistochemical staining (10). We believe that if automation of immunohistochemistry is in question in a pathology laboratory in our country, whether the annual immunohistochemistry number is optimal should be evaluated in addition to the number of technicians required and time and cost calculations stated above.

Histochemical staining is gradually used less frequently throughout the world. It is stated that 1 histochemical staining is performed per 4 cases (3). According to the results of our survey, the situation seems different in our country, and the number per case can be up to 1 . Automation of histochemical staining is preferred less in our country as well but whether the application is optimal for the laboratory should be evaluated as for immunohistochemistry.

Immunofluorescence staining is used more often in training hospitals, as expected. Immunofluorescence staining was performed in 23 of UH (70\%), 14 of TH (36\%), and 2 of PH (5.5\%). The application rate also seems to be related to the number of biopsies. The numbers might be considered to be at levels that meet the needs of our country; however, the distribution of the performing hospitals should also be studied. It was used in 7 centers in Ankara, 6 in İzmir, 5 in İstanbul, and 2 in Adana. The others can be stated to display a distribution that will serve the whole country (4 in the Central Anatolia Region, 2 in the Marmara Region, 2 in the Aegean Region, 2 in the Eastern Anatolia Region, 2 in the Southeastern Anatolia Region, 1 in the Mediterranean Region and 1 in the Black Sea Region).

Among cytological preparation methods, the use of cytocentrifugation, cell blocks and liquid-based methods was shown to be related both to hospitals and biopsy numbers. It can be stated that cytocentrifugation and cell blocks are required methods for proper and sufficient diagnosis. Liquid-based techniques were employed in 10 $\mathrm{UH}(30 \%), 2 \mathrm{TH}(5 \%), 15 \mathrm{SH}(8.5 \%)$ and $41 \mathrm{PH}(27 \%)$ and the high rates of usage were notable. The inclusion of this method in the 2010 Budget List as a different and higherpriced procedure might have resulted in its becoming widespread.

There is no archive regulation for pathology in our country. There are different regulations that can be used for the subject, and this results in confusion (1). This confusion can be clearly observed in the survey results. Archive periods were defined to be 20 years for blocks, 10 years for slides, 20 years for reports and indefinite for electronic records in the Private Hospitals Quality Standards Guide of the Ministry of Health (11). The formalization of these periods will be ensured by their inclusion in the updated new version of the clinical laboratory regulations. When these periods are accepted as threshold values, it is remarkable that they are not obeyed by $32.1 \%$ of units for reports, $47.9 \%$ for blocks, $10.1 \%$ for slides and $17.1 \%$ for sampled fixed tissues. It is known that many laboratories have problems in terms of archiving because of a shortage of space. Lack of staff and inability to cool of block archives in warm cities are also thought to be reasons for not attaching proper importance to archiving. 
The data on setting standards for pathology laboratories is inadequate in the literature. The European Society of Pathology suggests a total area of $321 \mathrm{~m}^{2}$ for hospital pathology laboratories whose annual number of biopsies is 15.000-20.000, including $41.5 \mathrm{~m}^{2}$ general laboratory area, $13 \mathrm{~m}^{2}$ histopathology area, $38.5 \mathrm{~m}^{2}$ macroscopy, tissue follow-up and archive area, $23.5 \mathrm{~m}^{2}$ cytology area, $26.5 \mathrm{~m}^{2}$ cytology screening area, $22.5 \mathrm{~m}^{2}$ laboratory offices, 34.5 $\mathrm{m}^{2}$ medical offices, $8 \mathrm{~m}^{2}$ secretariat area, $13 \mathrm{~m}^{2}$ chemical storage area, $15 \mathrm{~m}^{2}$ archive area, $85 \mathrm{~m}^{2}$ employee rooms and additional areas (12). These area suggestions do not seem to be appropriate for our country because of differences in working conditions and areas. Considering that there are no cytology scanners and fine-needle aspiration applications, this area should be decreased to at least $260 \mathrm{~m}^{2}$. These numbers are not logical for laboratories whose biopsy numbers, working conditions, and areas are different. Thus, the Standardization Commission of the Turkish Federation of Pathology Societies has calculated that a basic pathology laboratory should be at least $50 \mathrm{~m}^{2}$ in size, considering devices used and excluding the office areas. According to the survey results, there usually seems to be no problem regarding areas in $\mathrm{UH}$ and $\mathrm{TH}$. All areas are smaller in $\mathrm{PH}$ and $\mathrm{SH}$ compared to $\mathrm{UH}$ and $\mathrm{TH}$. However, it is notable that studies are carried out in areas less than the minimum $50 \mathrm{~m}^{2}$ area that we have determined in 94 (34\%) of 274 laboratories which responded to the survey. Of these 94 laboratories, 72 (77\%) are $\mathrm{SH}$ and 15 (16\%) are $\mathrm{PH}$. Quality in pathology has been taken more seriously and emphasized in recent years, and studies on the subject have increased especially after the Turkish Federation of Pathology Soceties was founded. The Ministry of Health has started to set standards on quality control, too. These studies, continuing on several fronts, will elevate pathology laboratories that have been ignored by hospital administrations until the recent past to the level they deserve.

The threshold value for work flow productivity is stated to be 4 (3). It is specified that the laboratories whose work flow productivity value is smaller than 4 are unproductive and that the reasons lowering this value could be excess personnel, unproductive performances in some procedures or both these reasons, and the reason should be identified and resolved (3). In our country, it is notable that WFP values are at the threshold in $\mathrm{UH}$ and $\mathrm{TH}$, and that $\mathrm{PH}$ and $\mathrm{SH}$ and in general hospitals with an annual number of biopsies $<10.000$ work unproductively. Productivity is observed to increase with increasing annual number of biopsies. Device automation accompanying increasing biopsy numbers can be said to play a role as important as the number of staff.
In conclusion, we think that all pathology laboratories in our country should evaluate and improve their own productivity. Improvements in physical conditions should be ensured, with the support of administration, in a large number of laboratories. Pathology-specific archiving periods need to be formalized. Otherwise, our colleagues may have problems with possible future malpractice suits. Turkish Federation of Pathology Societies has a lot of work to do on all these matters. Informative meetings on related subjects must be arranged, and finding a solution to problems with the relevant legal and administrative units must be targeted. As many colleagues as possible should provide support and contribution during this period.

\section{REFERENCES}

1. Buesa RJ: Histology: a unique area of the medical laboratory. Ann Diagn Pathol 2007, 11:137-141

2. Yörükoğlu K, Usubütün A, Doğan Ö, Önal B, Aydın Ö: Türkiye'de patoloji laboratuvarlarının genel profili. Turk Patoloji Derg 2009, 25:19-28

3. Buesa RJ: Productivity standards for histology laboratories. Ann Diagn Pathol 2010, 14:107-124

4. Usubütün A, Uner S, Harorlu F, Ozer E, Tuzlali S, Ruacan A, Koç O, Yörükoğlu K: Pathology laboratories staff workload evaluation in Turkey: a survey study. Turk Patoloji Derg 2011, 27:98-105

5. Yörükoğlu K, Usubütün A, Doğan Ö, Önal B, Aydın Ö: Türkiye'de patoloji laboratuvarlarında kalite kontrol. Turk Patoloji Derg 2009, 25:29-37

6. Patoloji Dernekleri Federasyonu Strateji Raporu, 2010. Available from: http://www.turkpath.org.tr/files/Patoloji_Strateji_Raporu. pdf

7. Buesa RJ: Staffing benchmarks for histology laboratories. Ann Diagn Pathol 2010, 14:182-193

8. Buesa RJ: Department dollars. Sharing costs of histology. Advance MLP 2007, 19:22-23

9. Muirhead D, Aoun P, Powell M, Juncker F, Mollerup J: Pathology economic model tool. A novel approach to workflow and budget cost analysis in an anatomic pathology laboratory. Arch Pathol Lab Med 2010, 134:1164-1169

10. Eisen RN: Quality management in immunohistochemistry. Diag Histopathol 2008, 14:299-307

11. T. C. Sağlık Bakanlığı, Özel Hastaneler Hizmet Kalite Standartları. 2009. Available from: http://www.performans.saglik.gov.tr/ content/files/yayinlar/ozel_hastane_hks.pdf

12. Simpson R, Marichal M, Uccini S: European Society of Pathology Statement on minimal requirements for a pathology laboratory. Discussion paper for the European Society of Pathology Executive Committee, Kiel, Saturday, 13 February 1999, Amended on Thursday, 16 September 1999. Virchows Arch 2000, 436:509-526

13. Buesa RJ: Adapting lean to histology laboratories. Ann Diagn Pathol 2009, 13:322-333

14. Serrano L, Hegge P, Sato B, Richmond B, Stahnke L: Using LEAN principles to improve quality, patient safety, and workflow in histology and anatomic pathology. Adv Anat Pathol 2010, 17: 215-221 